\title{
POTENSI ANTIDIARE EKSTRAK ETANOL BIJI PINANG (Areca catechu L.) TERHADAP MENCIT PUTIH
}

\author{
Marlyan Bone*, Aditya Fridayanti, Laode Rijai \\ Laboratorium Penelitian dan Pengembangan Kefarmasian "Farmaka Tropis", \\ Fakultas Farmasi, Universitas Mulawarman, Samarinda \\ *Email : marlyanbone@gmail.com
}

\begin{abstract}
This study examined the antidiarrheal potential effect of areca nut ethanol extract to male mice. Antidiarrheal testing is conducted by providing oleum ricini as diarrhea inducers and continued by providing orally ethanol extract of areca nut with a dose of $250 \mathrm{mg} / \mathrm{kg}, 300 \mathrm{mg} / \mathrm{kg}$ and $350 \mathrm{mg} / \mathrm{kg}$ respectively, and loperamide $\mathrm{HCl}$ is used as a comparison. The results show that a dose of $250 \mathrm{mg} / \mathrm{kg}, 300 \mathrm{mg} / \mathrm{kg}$, and $350 \mathrm{mg} / \mathrm{kg}$ have antidiarrheal activity. The obtained were processed using twoway analysis of variance and followed by Tukey's test on the ethanol extract of areca nut. The analysis showed that the best dose of ethanol extract of areca nut is $350 \mathrm{mg} / \mathrm{kg}$. The best dose was compared with loperamide $\mathrm{HCl}$ using independent $\mathrm{t}$ test and we find that the $350 \mathrm{mg} / \mathrm{kg}$ dose has the similar effect with loperamid HCL.
\end{abstract}

Keywords: Areca nut, Antidiarrheal.

\begin{abstract}
ABSTRAK
Telah dilakukan penelitian uji potensi antidiare ekstrak etanol biji pinang (Areca catechu L.) terhadap mencit putih jantan. Pengujian antidiare dilakukan dengan memberikan oleum ricini sebagai penginduksi diare dan dilanjutkan dengan pemberian ekstrak etanol biji pinang dengan dosis $250 \mathrm{mg} / \mathrm{kg} \mathrm{BB}, 300 \mathrm{mg} / \mathrm{kg} \mathrm{BB}$ dan $350 \mathrm{mg} / \mathrm{kg}$ BB secara oral serta digunakan loperamid $\mathrm{HCl}$ sebagai pembanding. Hasil pengamatan menunjukkan bahwa dosis $250 \mathrm{mg} / \mathrm{kg} \mathrm{BB}, 300 \mathrm{mg} / \mathrm{kg}$ BB dan $350 \mathrm{mg} / \mathrm{kg}$ BB memiliki aktivitas antidiare. Data yang diperoleh diolah menggunakan analisis varians dua arah dan dilanjutkan dengan uji Tukey HSD (homestly significant diference) pada ekstrak etanol biji pinang. Hasil analisis menunjukkan bahwa dosis terbaik dari ekstrak etanol biji pinang adalah $350 \mathrm{mg} / \mathrm{kg}$ $\mathrm{BB}$. Data dosis terbaik dibandingkan dengan loperamid $\mathrm{HCl}$ menggunakan uji t test independent yang menghasilkan dosis $350 \mathrm{mg} / \mathrm{kg} \mathrm{BB}$ memiliki efek yang sama dengan loperamid $\mathrm{HCl}$.
\end{abstract}


Kata Kunci : Biji pinang, Antidiare.

\section{PENDAHULUAN}

Diare merupakan salah satu penyebab utama morbiditas dan kematian diberbagai negara, serta bertanggung jawab atas kematian jutaan orang setiap tahunnya. Tingginya angka kejadian diare akut dan diare kronis serta efek samping obat antidiare yang ada saat ini, mendorong para peneliti untuk terus berusaha dalam menemukan obat sebagai antidiare baru, terutama yang berasal dari tanaman obat tradisional sebagai antidiare yaitu dengan cara melihat efek biologis ekstrak tanaman yang mempunyai aktivitas sebagai antispasmodik, penunda transit intestinal, menekan motilitas usus, merangsang absorpsi air dan mengurangi sekresi elektrolit [1]. Dikarenakan banyaknya efek samping penggunaan obat-obat modern atau obat sintetik. Semakin berkembangnya ilmu pengetahuan menyebabkan orang sadar akan keunggulan bahan alam. Obat-obat tradisional tersebut, dalam kehidupan sehari-hari tidak dapat digunakan sebagai obat modern karena tidak dapat diresepkan sehingga perlu dilakukan penelitian lebih lanjut tentang kandungan kimia dari obat tersebut dan diuji secara klinis [2].

Salah satu tanaman obat yang sudah dimanfaatkan secara tradisional adalah tanaman pinang (Areca catechu L.) terutama bagian bijinya. Biji pinang dapat digunakan untuk obat cacingan, perut kembung, edema, luka, batuk berdahak, diare dan malaria. Kandungan metabolit sekunder biji pinang yaitu alkaloid, tanin dan lemak [3]. Secara empiris biji pinang dapat digunakan untuk mengobati penyakit diare dengan cara buah pinang yang warnanya kuning muda dicuci lalu direndam dalam 1 gelas air selama beberapa jam (1-2 jam) kemudian air rendaman pinang tersebut diminum. Selain itu, biji pinang ini dapat digunakan untuk mencret dan masalah buang air besar yang berdarah dengan cara meminum air parutan biji pinang tersebut [4].

\section{METODE PENELITIAN}

\section{Bahan}

Bahan yang diteliti adalah simplisia biji pinang. Bahan yang digunakan adalah pelarut etanol $70 \%$, oleum ricini, $\mathrm{Na} \mathrm{CMC}$, air suling dan kertas saring. Hewan uji yang digunakan adalah mencit putih jantan (Mus musculus).

\section{Peralatan}

Peralatan yang digunakan dalam penelitian ini antara lain wadah maserasi, rotary evaporator, waterbath, timbangan analitik, cawan porselin, sonde oral, lumpang dan alu, labu ukur, gelas kimia dan alat penunjang lainnya. 


\section{PROSEDUR}

\section{Pengambilan Sampel}

Biji pinang diperoleh dari sungai dama Kota Samarinda, Kalimantan Timur. Biji pinang segar dikumpulkan kemudian disortasi basah. Setelah itu, dicuci, dipotong kecil-kecil dan dikeringkan dengan menggunakan oven pada suhu $40{ }^{\circ} \mathrm{C}$. Selanjutnya biji pinang disortasi kering dan dihaluskan menjadi serbuk simplisia.

\section{Ekstraksi}

Serbuk simplisia dimasukkan ke dalam wadah maserasi dan dimaserasi menggunakan pelarut etanol $70 \%$. Proses maserasi berlangsung selama kurang lebih 3 hari. Maserat (hasil maserasi) disaring menggunakan kertas saring dan ditampung ke dalam wadah. Kemudian dipekatkan menggunakan rotary evaporator dan dilanjutkan dengan penguapan di atas waterbath hingga diperoleh ekstrak kental etanol biji pinang.

\section{Pengujian Aktivitas Antidiare}

Hewan uji dibagi menjadi enam kelompok, kelompok I tidak diberi perlakuan, kelompok II diberikan oleum ricini, kelompok III diberikan loperamid $\mathrm{HCl}$ dan kelompok lainnya adalah variasi dosis $250 \mathrm{mg} / \mathrm{kg} \mathrm{BB}, 300 \mathrm{mg} / \mathrm{kg}$ BB dan $350 \mathrm{mg} / \mathrm{kg} \mathrm{BB}$, dimana setiap kelompok terdiri dari 4 ekor mencit putih jantan. Sebelum diberi perlakuan mencit putih jantan diadaptasikan terlebih dahulu selama 2 minggu. Sesaat sebelum diberi perlakuan mencit putih jantan dipuasakan selama 1 jam, setelah dipuasakan kelompok I tidak diberi perlakuan. Selanjutnya kelompok II sampai VI diberikan oleum ricini sebanyak $0,5 \mathrm{~mL}$ sebagai penginduksi diare. Tiga puluh menit kemudian kelompok II diberikan Na CMC sebagai kontrol negatif, kelompok III diberikan loperamid $\mathrm{HCl}$ sebagai kontrol positif, kelompok IV diberikan ekstrak etanol biji pinang dengan dosis $250 \mathrm{mg} / \mathrm{kg} \mathrm{BB}$, kelompok V diberikan ekstrak etanol biji pinang dengan dosis $300 \mathrm{mg} / \mathrm{kg}$ BB dan kelompok VI diberikan ekstrak etanol biji pinang dengan dosis $350 \mathrm{mg} / \mathrm{kg}$ BB. Dilakukan pengamatan setiap 60 menit selama 10 jam pada mencit putih jantan meliputi frekuensi diare, diameter feses $(\mathrm{cm})$ dan lama terjadinya diare (menit).

\section{HASIL DAN PEMBAHASAN}

\section{Aktivitas Antidiare Ekstrak etanol biji pinang}

Aktivitas antidiare diperoleh dari data frekuensi diare, diameter serapan feses $(\mathrm{cm})$ dan lama terjadinya diare (menit).

\section{a. Aktivitas ekstrak berdasarkan frekuensi diare}

Aktivitas ekstrak etanol biji pinang berdasarkan frekuensi diare dapat dilihat pada tabel 1. 
Tabel 1. Data aktivitas antidiare berdasarkan frekuensi diare

\begin{tabular}{|c|c|c|c|c|c|c|}
\hline \multirow{2}{*}{ Perlakuan } & \multicolumn{4}{|c|}{ Hewan uji ke- } & \multirow{2}{*}{ Jumlah } & \multirow{2}{*}{ Rerata } \\
\hline & 1 & 2 & 3 & 4 & & \\
\hline Kontrol negatif & 30 & 25 & 22 & 24 & 101 & 25,25 \\
\hline $250 \mathrm{mg} / \mathrm{kg} \mathrm{BB}$ & 13 & 13 & 18 & 16 & 60 & 15 \\
\hline $300 \mathrm{mg} / \mathrm{kg} \mathrm{BB}$ & 18 & 15 & 17 & 14 & 64 & 16 \\
\hline $350 \mathrm{mg} / \mathrm{kg} \mathrm{BB}$ & 16 & 14 & 15 & 7 & 52 & 13 \\
\hline
\end{tabular}

Tabel 1 menunjukkan pengamatan frekuensi terjadinya diare, dimana pada dosis $250 \mathrm{mg} / \mathrm{kg}$ BB rata-ratanya $15 \mathrm{kali}$, dosis $300 \mathrm{mg} / \mathrm{kg}$ BB sebanyak $16 \mathrm{kali}$, dosis $350 \mathrm{mg} / \mathrm{kg}$ BB sebanyak 13 kali yang dibandingkan dengan kontrol negatif yaitu Na CMC sebanyak 25,2 kali. Hal tersebut menunjukkan bahwa ekstrak etanol biji pinang memiliki aktivitas mengurangi diare yang dibandingkan dengan kontrol negatif yaitu Na CMC. Grafik frekuensi diare ekstrak etanol biji pinang dapat dilihat pada gambar 1 .

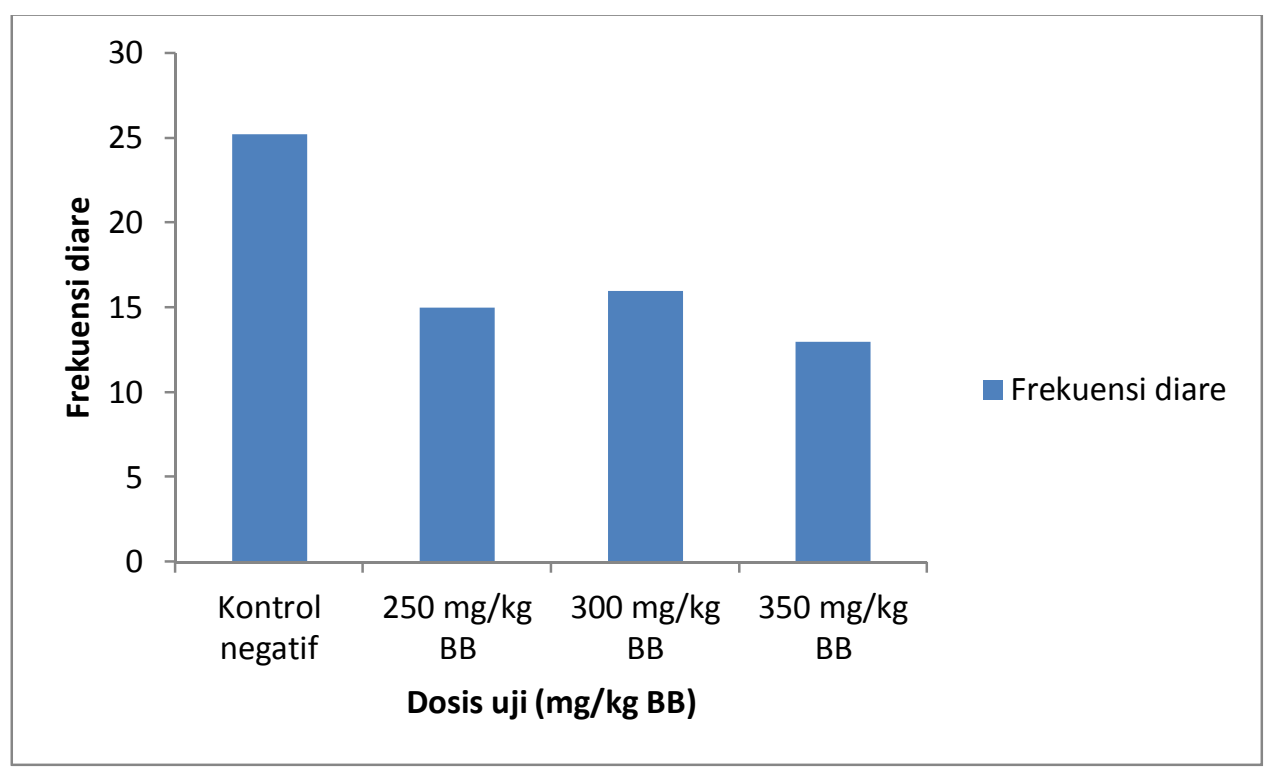

Gambar 1. Grafik pengaruh ekstrak etanol biji pinang berdasarkan frekuensi diare

Dari hasil yang diperoleh menunjukkan dengan semakin tinggi frekuensi terjadinya diare maka aktivitas antidiare akan semakin lemah dan sebaliknya semakin rendah frekuensi diare maka semakin kuat aktivitas antidiare.

\section{b. Aktivitas ekstrak berdasarkan diameter serapan feses (cm)}


Aktivitas ekstrak etanol biji pinang berdasarkan diameter serapan feses $(\mathrm{cm})$ dapat dilihat pada tabel 2 .

Tabel 2. Data aktivitas antidiare berdasarkan diameter serapan feses $(\mathrm{cm})$

\begin{tabular}{|c|c|c|c|c|c|c|}
\hline \multirow{2}{*}{ Perlakuan } & \multicolumn{4}{|c|}{ Hewan uji ke- } & \multirow{2}{*}{ Jumlah } & \multirow{2}{*}{ Rerata } \\
\hline & 1 & 2 & 3 & 4 & & \\
\hline Kontrol negatif & 46,3 & 48,7 & 34,4 & 29,8 & 159,2 & 39,8 \\
\hline $250 \mathrm{mg} / \mathrm{kg} \mathrm{BB}$ & 15,5 & 30,9 & 27,4 & 21,65 & 95,45 & 23,8 \\
\hline $300 \mathrm{mg} / \mathrm{kg} \mathrm{BB}$ & 28,4 & 25 & 46,6 & 13,4 & 113,4 & 28,3 \\
\hline $350 \mathrm{mg} / \mathrm{kg} \mathrm{BB}$ & 38,1 & 2,6 & 1,8 & 11,2 & 69,9 & 17,4 \\
\hline
\end{tabular}

Tabel 2 menunjukkan pengamatan diameter serapan feses, dimana pada dosis $250 \mathrm{mg} / \mathrm{kg}$ BB rata-ratanya $23,8 \mathrm{~cm}$, dosis $300 \mathrm{mg} / \mathrm{kg}$ BB sebanyak $28,3 \mathrm{~cm}$, dosis $350 \mathrm{mg} / \mathrm{kg}$ BB sebanyak 17,4 cm yang dibandingkan dengan kontrol negatif yaitu $\mathrm{Na}$ CMC sebanyak $39,8 \mathrm{~cm}$. Hal tersebut menunjukkan bahwa ekstrak etanol biji pinang memiliki aktivitas mengurangi diare yang dibandingkan dengan kontrol negatif yaitu $\mathrm{Na} \mathrm{CMC}$. Grafik diameter serapan feses ekstrak etanol biji pinang dapat dilihat pada gambar 2 .

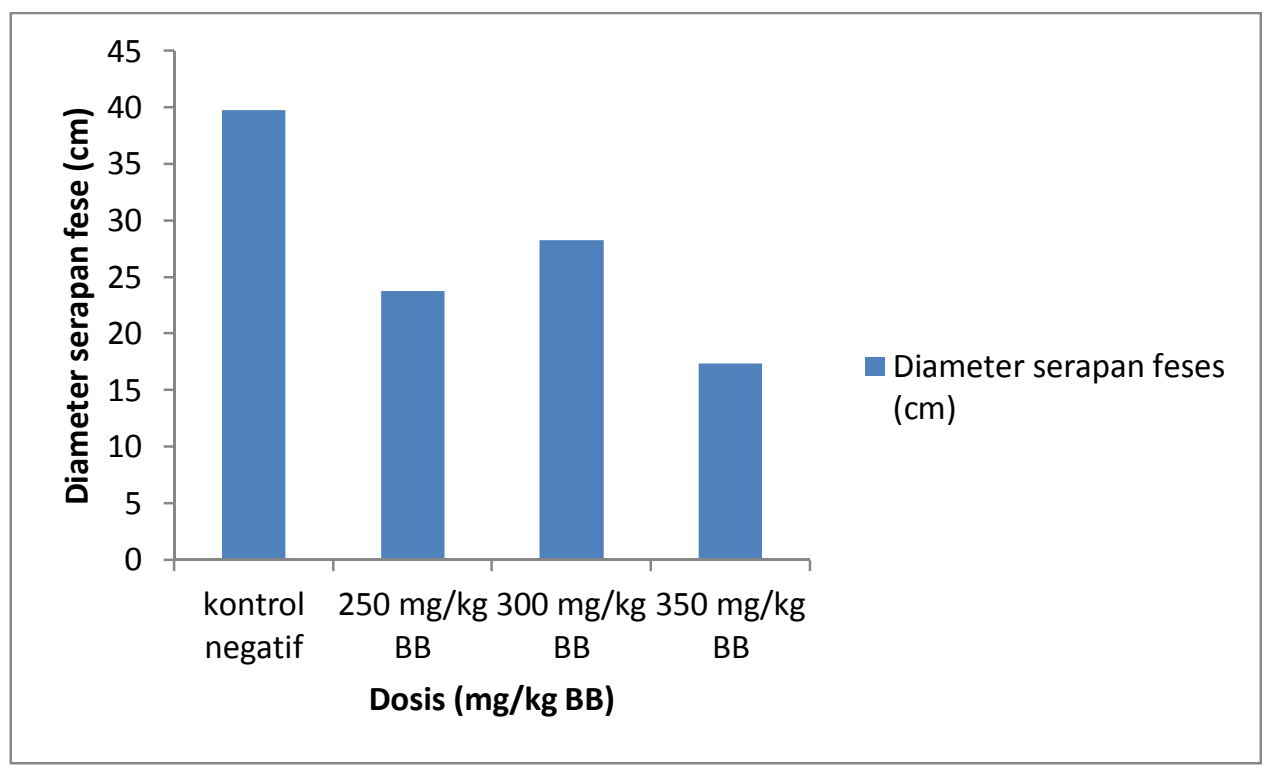

Gambar 2. Grafik pengaruh ekstrak etanol biji pinang berdasarkan diameter serapan feses $(\mathrm{cm})$ 
Dari hasil yang diperoleh menunjukkan dengan semakin tinggi diameter serapan feses maka aktivitas antidiare akan semakin lemah dan sebaliknya semakin rendah frekuensi diare maka semakin kuat aktivitas antidiare.

\section{c. Aktivitas antidiare berdasarkan lama terjadinya diare (menit)}

Aktivitas ekstrak etanol biji pinang berdasarkan lama terjadinya diare dapat dilihat pada tabel 3 .

Tabel 3. Data aktivitas antidiare berdasarkan lama terjadinya diare (menit)

\begin{tabular}{|c|c|c|c|c|c|c|}
\hline \multirow{2}{*}{ Perlakuan } & \multicolumn{4}{|c|}{ Hewan uji ke- } & \multirow{2}{*}{ Jumlah } & \multirow{2}{*}{ Rerata } \\
\hline & 1 & 2 & 3 & 4 & & \\
\hline Kontrol negatif & 645 & 557 & 475 & 350 & 2027 & 506,75 \\
\hline $250 \mathrm{mg} / \mathrm{kg} \mathrm{BB}$ & 475 & 520 & 525 & 430 & 1950 & 487,5 \\
\hline $300 \mathrm{mg} / \mathrm{kg} \mathrm{BB}$ & 203 & 495 & 130 & 180 & 1008 & 252 \\
\hline $350 \mathrm{mg} / \mathrm{kg} \mathrm{BB}$ & 85 & 191 & 62 & 229 & 567 & 141,75 \\
\hline
\end{tabular}

Tabel 3 menunjukkan pengamatan lama terjadinya diare, dimana pada dosis $250 \mathrm{mg} / \mathrm{kg}$ BB rata-ratanya 487,5 menit, dosis $300 \mathrm{mg} / \mathrm{kg}$ BB selama 252 menit, dosis $350 \mathrm{mg} / \mathrm{kg}$ BB selama 141,75 menit yang dibandingkan dengan kontrol negatif yaitu $\mathrm{Na}$ CMC selama 506,75 menit. Hal tersebut menunjukkan bahwa ekstrak etanol biji pinang memiliki aktivitas mengurangi diare yang dibandingkan dengan kontrol negatif yaitu Na CMC. Grafik lama diare ekstrak etanol biji pinang dapat dilihat pada gambar 3 . 


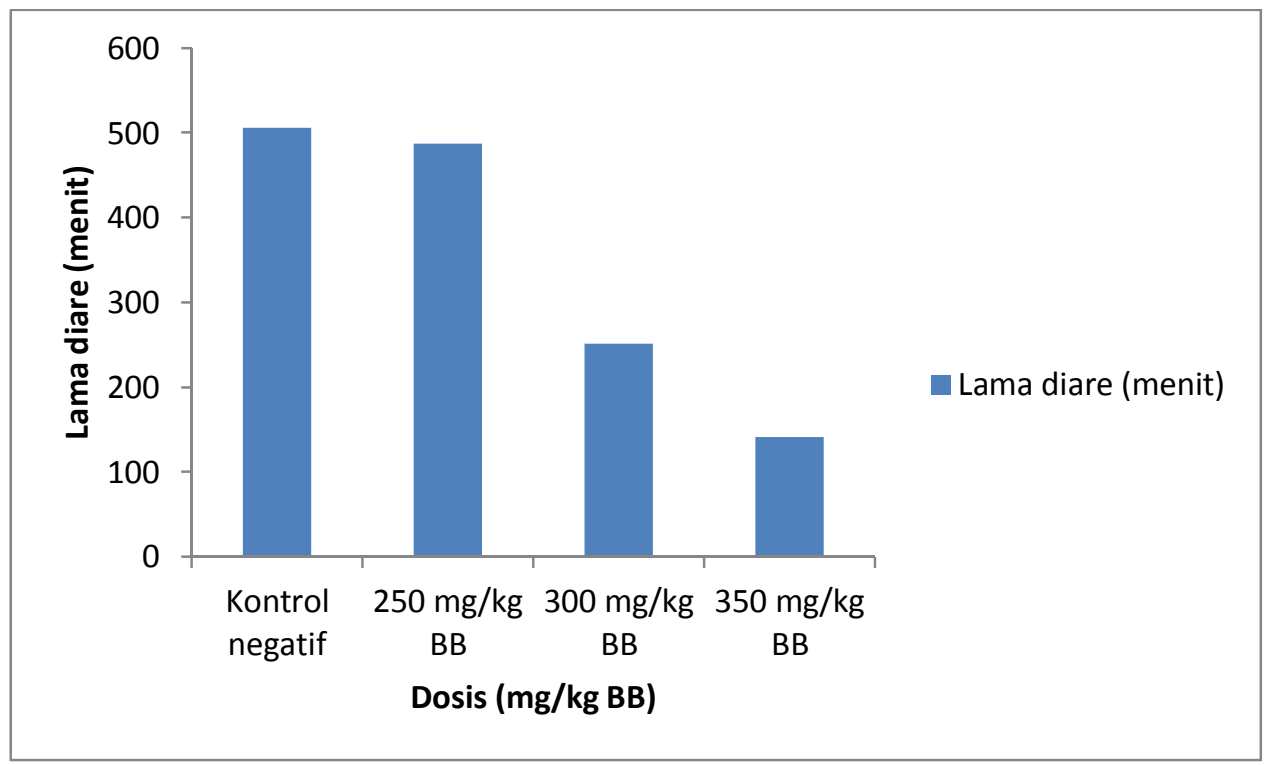

Gambar 3. Grafik pengaruh ekstrak etanol biji pinang berdasarkan lama diare (menit)

Dari hasil yang diperoleh menunjukkan dengan semakin tingginya lama diare maka aktivitas antidiare akan semakin lemah dan sebaliknya semakin rendah lama terjadinya diare maka semakin kuat aktivitas antidiare.

\section{Dosis terbaik ekstrak etanol biji pinang sebagai antidiare}

\section{a. Berdasarkan frekuensi diare}

Hasil perhitungan uji normalitas dan homogenitas dapat dilihat pada Tabel 4 dan 5.

Tabel 4. Uji normalitas aktivitas antidiare berdasarkan frekuensi terjadinya diare

\begin{tabular}{ccc}
\hline \multicolumn{3}{c}{ Shapiro-Wilk } \\
\hline statistic & $\mathrm{df}$ & Sig \\
.934 & 16 & .286 \\
\hline
\end{tabular}

Tabel 4 menunjukkan bahwa pada statistik uji normalitas Shapiro-Wilk didapatkan varians data pada dosis memiliki signifikansi lebih dari 0,05 (sig > 0,05), oleh karena itu dapat disimpulkan bahwa distribusi kelompok data aktivitas antidiare berdasarkan frekuensi terjadinya diare adalah normal. 
Tabel 5. Uji homogenitas aktivitas antidiare berdasarkan frekuensi terjadinya diare

\begin{tabular}{ccccccc}
\hline Levene Statistic & df1 & df2 & Sig. \\
\hline & .657 & & 3 & & 12 & .594 \\
\hline
\end{tabular}

Tabel 5 menunjukkan bahwa varians data memiliki signifikansi lebih dari $0,05$ ( sig $>0,05)$, maka dapat diambil kesimpulan bahwa varians dalam kelompok data frekuensi terjadinya diare adalah homogen.

Berdasarkan hasil analisis data yang diperoleh disimpulkan bahwa data frekuensi terjadinya diare terdistribusi normal dan memiliki varians yang homogen, sehingga dapat dilanjutkan menggunakan uji anava dua arah. Hasil perhitungan Anava untuk frekuensi terjadinya diare dapat dilihat pada Tabel 6.

Tabel 6. Anava dua arah berdasarkan frekuensi diare

\begin{tabular}{lrrrrr}
\hline & Sum of Squares & df & Mean Square & F & Sig. \\
\hline Between Groups & 354.687 & 3 & 118.229 & 13.719 & .001 \\
\hline
\end{tabular}

Tabel 6 menunjukkan bahwa berdasarkan nilai signifikansi yang besarnya 0,001 , dimana signifikansi kurang dari $\alpha$ yaitu 0,05 , sehingga dapat dikatakan bahwa diantara variasi dosis terdapat perbedaan yang signifikan dalam memberikan aktivitas sebagai antidiare. Selanjutnya untuk mengetahui dosis yang paling berbeda diantara kelompok dosis tersebut, yang akan menjadi dosis terbaik ekstrak etanol biji pinang dilanjutkan dengan uji Tukey HSD yang dapat dilihat pada tabel 7.

Tabel 7. Homogeneous subsets

\begin{tabular}{cccc}
\hline Dosis & $\mathrm{N}$ & \multicolumn{2}{c}{ Subset } \\
\cline { 3 - 4 } & & 13.000 & 2 \\
$250 \mathrm{mg}$ & 4 & 15.000 & \\
$300 \mathrm{mg}$ & 4 & 16.000 & 25.2500 \\
\hline Kontrol negatif & 4 & & 1.000 \\
\hline Sig. & & .505 & \\
\hline
\end{tabular}

Hasil uji Tukey HSD pada Tabel 7 homogeneous subsets di atas menunjukkan bahwa dosis ekstrak dalam menimbulkan frekuensi terjadinya diare adalah dosis $300 \mathrm{mg} / \mathrm{kg}$ BB karena memiliki nilai yang paling tinggi yaitu 16.000 sedangkan dosis $350 \mathrm{mg} / \mathrm{kg}$ BB memiliki nilai lebih rendah yaitu 13.000. Dari hasil tersebut dapat disimpulkan bahwa dosis terbaik ekstrak etanol biji pinang sebagai antidiare adalah dosis $350 \mathrm{mg} / \mathrm{kg} \mathrm{BB}$. 


\section{b. Berdasarkan lama diare (menit)}

8 dan 9.

Hasil perhitungan uji normalitas dan homogenitas dapat dilihat pada Tabel

Tabel 8. Uji normalitas aktivitas antidiare berdasarkan lama terjadinya diare

\begin{tabular}{ccc}
\hline \multicolumn{3}{c}{ Shapiro-Wilk } \\
\hline statistic & $\mathrm{df}$ & Sig \\
.916 & 16 & .143 \\
\hline
\end{tabular}

Tabel 8 menunjukkan bahwa pada statistik uji normalitas Shapiro-Wilk didapatkan varians data pada dosis memiliki signifikansi lebih dari 0,05 (sig > $0,05)$, oleh karena itu dapat disimpulkan bahwa distribusi kelompok data aktivitas antidiare berdasarkan lama diare adalah normal.

Tabel 9. Uji homogenitas aktivitas antidiare berdasarkan lama terjadinya diare

\begin{tabular}{cccccr}
\hline Levene Statistic & df1 & df2 & Sig. \\
\hline 1.809 & & 3 & & 12 & .199 \\
\hline
\end{tabular}

Tabel 9 menunjukkan bahwa varians data memiliki signifikansi lebih dari $0,05$ ( $\operatorname{sig}>0,05)$, maka dapat diambil kesimpulan bahwa varians dalam kelompok data lama diare adalah homogen.

Berdasarkan hasil analisis data yang diperoleh disimpulkan bahwa data lama terjadinya diare terdistribusi normal dan memiliki varians yang homogen, sehingga dapat dilanjutkan menggunakan uji anava dua arah. Hasil perhitungan Anava untuk lama terjadinya diare dapat dilihat pada Tabel 10.

Tabel 10. Anava dua arah berdasarkan lama diare (menit)

\begin{tabular}{lcrccc}
\hline & Sum of Squares & df & Mean Square & F & Sig. \\
\hline Between Groups & 385651,500 & 3 & 128550,500 & 11.626 & .002 \\
\hline
\end{tabular}

Tabel 10 menunjukkan bahwa berdasarkan nilai signifikansi yang besarnya 0,002 , dimana signifikansi kurang dari $\alpha$ yaitu 0,05 , sehingga dapat dikatakan bahwa diantara variasi dosis terdapat perbedaan yang signifikan dalam memberikan aktivitas sebagai antidiare. Selanjutnya untuk mengetahui dosis yang paling berbeda diantara kelompok dosis tersebut, yang akan menjadi dosis terbaik ekstrak etanol biji pinang dilanjutkan dengan uji Tukey HSD yang dapat dilihat pada tabel 11. 
Tabel 11. Homogeneous subsets

\begin{tabular}{cccc}
\hline Dosis & $\mathrm{N}$ & \multicolumn{2}{c}{ Subset } \\
\cline { 3 - 4 } & 4 & 141.7500 & \\
\hline $350 \mathrm{mg}$ & 4 & 252.0000 & \\
$300 \mathrm{mg}$ & 4 & & 487.5000 \\
$250 \mathrm{mg}$ & 4 & & 506.7500 \\
\hline Kontrol negatif & & .485 & .993 \\
\hline Sig. & & & \\
\hline
\end{tabular}

Hasil uji Tukey HSD pada Tabel 11 homogeneous subsets di atas menunjukkan bahwa dosis ekstrak dalam menimbulkan lama terjadinya diare adalah dosis $250 \mathrm{mg} / \mathrm{kg}$ BB karena memiliki nilai yang paling tinggi yaitu 487.5000 sedangkan dosis $350 \mathrm{mg} / \mathrm{kg}$ BB memiliki nilai lebih rendah yaitu 141.7500. Dari hasil tersebut dapat disimpulkan bahwa dosis terbaik ekstrak etanol biji pinang sebagai antidiare adalah dosis $350 \mathrm{mg} / \mathrm{kg} \mathrm{BB}$.

\section{Potensi ekstrak etanol biji pinang sebagai antidiare}

Data hasil dosis terbaik yaitu $350 \mathrm{mg} / \mathrm{kg}$ BB dibandingkan dengan Loperamid $\mathrm{HCl}$ berdasarkan frekuensi terjadinya diare dan lama diare (menit).

\section{a. Berdasarkan frekuensi diare}

Tabel 12. Potensi antidiare ekstrak etanol biji pinang berdasarkan frekuensi diare

\begin{tabular}{|c|c|c|c|c|c|c|}
\hline \multirow{2}{*}{ Perlakuan } & \multicolumn{4}{|c|}{ Hewan uji ke- } & \multirow{2}{*}{ Jumlah } & \multirow{2}{*}{ Rerata } \\
\hline & 1 & 2 & 3 & 4 & & \\
\hline $\begin{array}{l}\text { Dosis } 350 \\
\mathrm{mg} / \mathrm{kg} \text { BB }\end{array}$ & 16 & 14 & 15 & 7 & 52 & 13 \\
\hline Loperamid $\mathrm{HCl}$ & 10 & 12 & 13 & 17 & 52 & 13 \\
\hline
\end{tabular}

Tabel 12 menunjukkan pengamatan frekuensi terjadinya diare, dimana pada dosis $350 \mathrm{mg} / \mathrm{kg}$ BB sebanyak 13 kali yang dibandingkan dengan kontrol positif yaitu yaitu Loperamid $\mathrm{HCl}$ sebanyak 13 kali. Hal tersebut menunjukkan bahwa ekstrak etanol biji pinang memiliki jumlah frekuensi diare yang sama dengan loperamid $\mathrm{HCl}$. Grafik frekuensi diare ekstrak etanol biji pinang dapat dilihat pada gambar 4. 


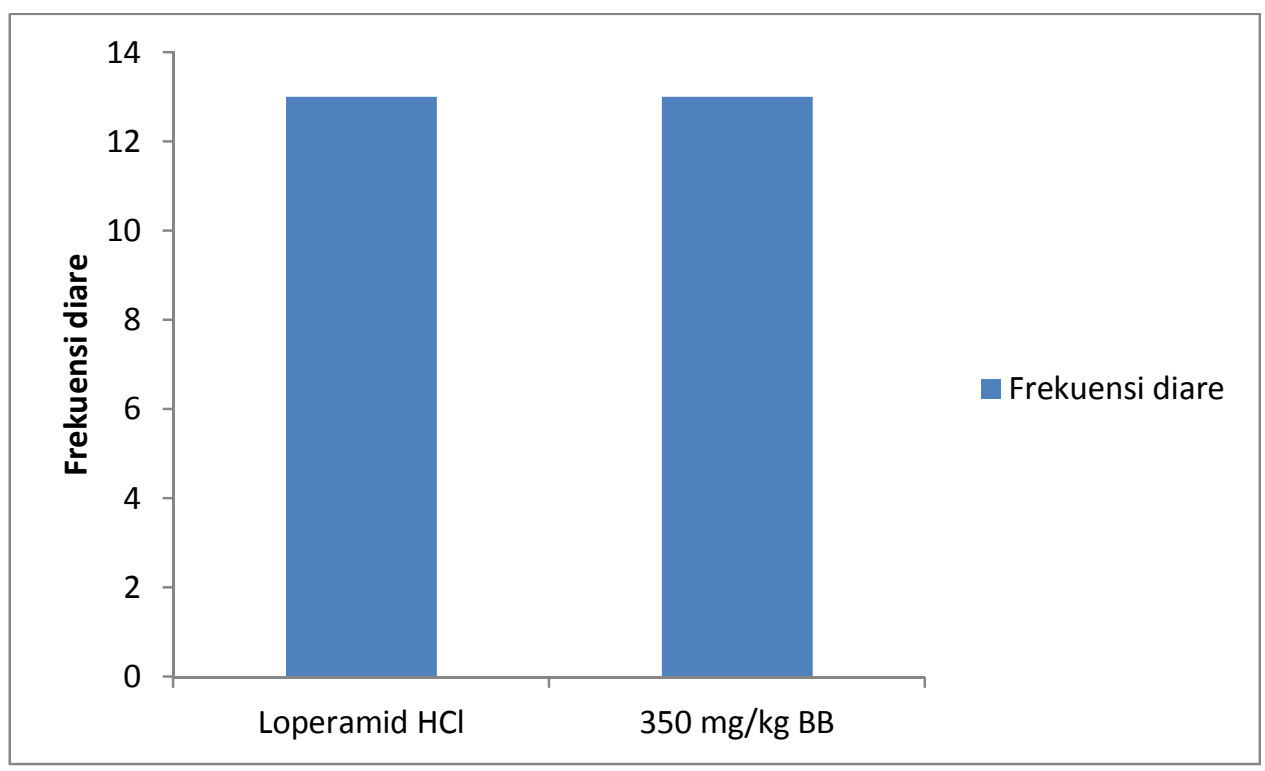

Gambar 4. Grafik pengaruh dosis $350 \mathrm{mg} / \mathrm{kg}$ BB dan Loperamid HCL berdasarkan frekuensi diare

Dari hasil yang diperoleh menunjukkan bahwa dosis $350 \mathrm{mg} / \mathrm{kg} \mathrm{BB}$ memiliki potensi yang sama (sebanding) dengan loperamid $\mathrm{HCl}$.

Untuk membuktikan tingkat kepercayaan atau kebenaran dari data gambar tersebut, maka data hasil uji aktivitas antidiare ekstrak etanol biji pinang dilakukan analisis uji $t$ test independent. Hasil perhitungan uji t test independent dapat dilihat pada Tabel 13.

Tabel 13. Uji $t$ test independent berdasarkan frekuensi diare

\begin{tabular}{cccccccccccc}
\hline \multicolumn{1}{c}{ Levene's Test for Equality of } \\
Variance
\end{tabular}

Dari tabel 13 menunjukkan bahwa nilai sigfinifikansi lebih besar dari 0.05, sehingga tidak ada perbedaan rata-rata yang signifikan frekuensi terjadinya diare antara yang menggunakan dosis ekstrak $350 \mathrm{mg} / \mathrm{kg}$ BB dan yang menggunakan loperamid $\mathrm{HCl}$. 


\section{b. Berdasarkan lama terjadinya diare (menit)}

Tabel 14. Potensi antidiare ekstrak etanol biji pinang berdasarkan lama diare (menit)

\begin{tabular}{|c|c|c|c|c|c|c|}
\hline \multirow{2}{*}{ Perlakuan } & \multicolumn{4}{|c|}{ Hewan uji ke- } & \multirow{2}{*}{ Jumlah } & \multirow{2}{*}{ Rerata } \\
\hline & 1 & 2 & 3 & 4 & & \\
\hline $\begin{array}{l}\text { Dosis } 350 \\
\mathrm{mg} / \mathrm{kg} \text { BB }\end{array}$ & 85 & 191 & 62 & 229 & 567 & 141,75 \\
\hline Loperamid $\mathrm{HCl}$ & 185 & 84 & 197 & 201 & 667 & 166,75 \\
\hline
\end{tabular}

Tabel 14 menunjukkan pengamatan lama terjadinya diare, dimana pada dosis $350 \mathrm{mg} / \mathrm{kg}$ BB sebanyak 141,75 menit yang dibandingkan dengan kontrol positif yaitu yaitu Loperamid $\mathrm{HCl}$ sebanyak 166,75 menit. Hal tersebut menunjukkan bahwa ekstrak etanol biji pinang memiliki jumlah waktu lama diare lebih sedikit dibandingkan dengan loperamid $\mathrm{HCl}$. Grafik frekuensi diare ekstrak etanol biji pinang dapat dilihat pada gambar 5 .

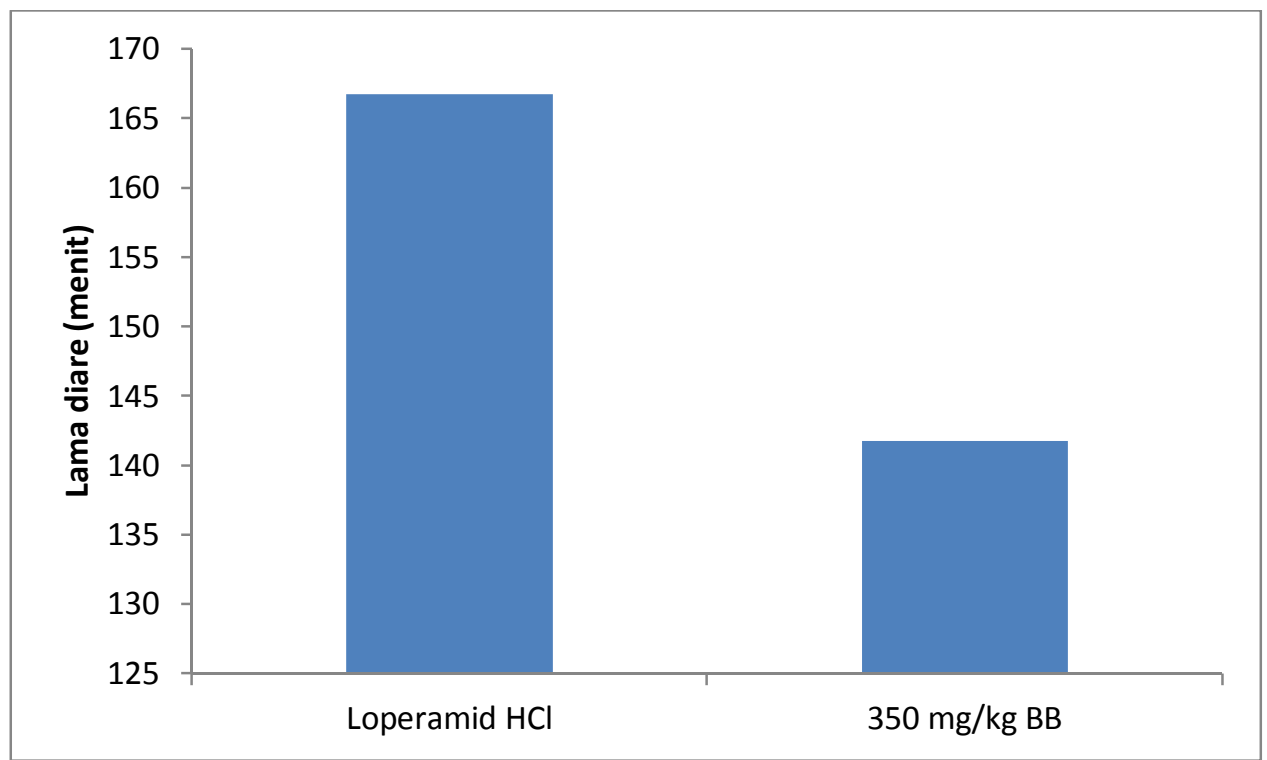

Gambar 5. Grafik pengaruh dosis $350 \mathrm{mg} / \mathrm{kg} \mathrm{BB}$ dan Loperamid $\mathrm{HCl}$ berdasarkan lama diare (menit)

Dari hasil yang diperoleh menunjukkan bahwa dosis $350 \mathrm{mg} / \mathrm{kg}$ BB memiliki potensi yang lebih kuat dibandingkan dengan loperamid $\mathrm{HCl}$.

Untuk membuktikan tingkat kepercayaan atau kebenaran dari data gambar tersebut, maka data hasil uji aktivitas antidiare ekstrak etanol biji pinang dilakukan analisis uji $t$ test independent. Hasil perhitungan uji $t$ test independent dapat dilihat pada Tabel 15. 
Tabel 15. Uji t test independent berdasarkan lama diare (menit)

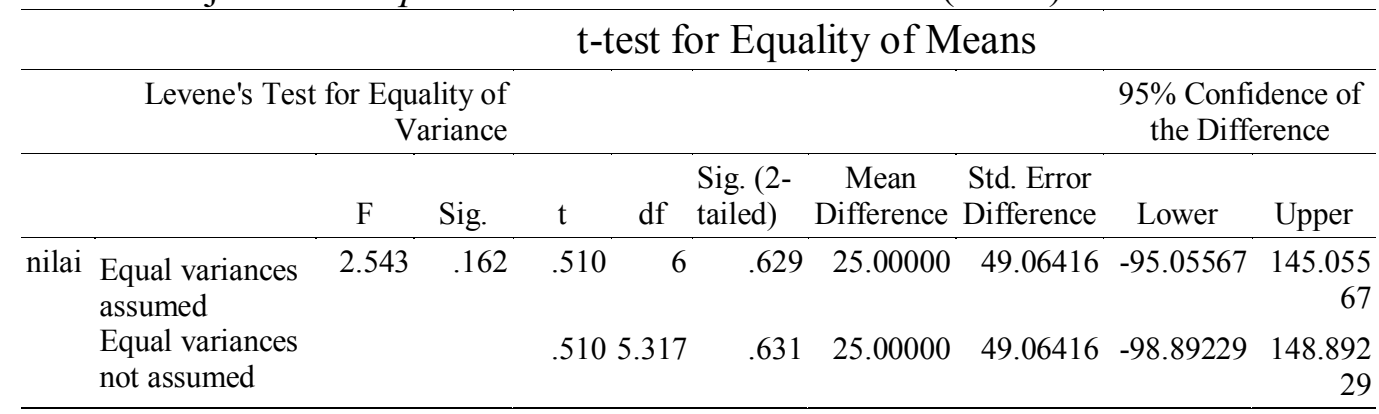

Dari tabel tersebut menunjukkan bahwa nilai sigfinifikansi lebih besar dari 0.05, sehingga tidak ada perbedaan rata-rata yang signifikan lama terjadinya diare antara yang menggunakan dosis ekstrak $350 \mathrm{mg} / \mathrm{kg}$ BB dan yang menggunakan loperamid $\mathrm{HCl}$.

\section{KESIMPULAN}

Ekstrak etanol biji pinang (Areca catechu L.) berpotensi sebagai antidiare dan dosis terbaik adalah $350 \mathrm{mg} / \mathrm{kg} \mathrm{BB}$.

\section{DAFTAR PUSTAKA}

[1] Palombo, E.A., 2006. Phytochemicals from Traditional Medicinal Plants Used in the Treatment of Diarrhoea : Modes of Action and Effects on Intestinal Function. Phytotherapy Research, 20(9) : 717-24.

[2] Kusmiyati.,Nurfina Aznam.,Sri Handayani. 2011. Isolasi dan Identifikasi Zat Aktif Ekstrak Metanol Rimpang Kunyit Putih (Curcuma mangga Val) Fraksi Etil Asetat. Jurnal Ilmiah Kefarmasian, Vol. 1, No. 2.

[3] Yuniarti, Titin. 2008. Ensiklopedia Tanaman Obat Tradisional. Media Pressindo. Yogyakarta.

[4] Suhono,Budi.,1999. Ensiklopedia Flora. PT. Kharisma Ilmu LIPI. Bogor 